\title{
SYNTHESIS OF 4-AMINO-3,5-DICYANO-ARYLPYRAZOLES. PART 2: ISOLATION AND CHARACTERIZATION OF BY-PRODUCTS
}

\author{
M.S.T. Gonçalves*, A.M.F. Oliveira-Campos, L.M. Rodrigues and M.F.R.P. Proença \\ Chemistry Centre, University of Minho, Campus de Gualtar, 4710-057 Braga, Portugal
}

\begin{abstract}
Reaction of (dicyanomethylidene-hydrazino)benzoic acids with chloroacetonitrile, under basic conditions, gave cyanomethyl-3-(7-amino-3,5-dicyano- $1 H$-pyrazolo[4,3- $d$ ]pyrimidin-1-ylbenzoates and para substituted cyanomethyl benzoates, in addition to the expected cyanomethyl 3(4-amino-3,5-dicyano-1H-pyrazol-1-yl)-benzoates.
\end{abstract}

Keywords: Pyrazolo[4,3- $d$ ]pyrimidines; aminopyrazoles; malononitrile; aminocyanopyrazoles

\section{INTRODUCTION}

Pyrazole derivatives are well recognised for their biological activities as potential HIV-1 inhibitors, antiviral, anticancer agents, insecticides and fungicides. ${ }^{[1-4]}$

Pyrazole fused-heterocycles, namely pyrazolo[4,3- $d]$ pyrimidine derivatives are also of great interest as potential biologically active molecules. Several members of this class exhibit recognised pharmacological activities for treatment of thromboembolic disorders, with affinity at adenosine receptors for the treatment of bronchoconstriction and cardiac insufficiency, as well as Hsp90 inhibitory activity. ${ }^{[5-7]}$

A classical method of pyrazole synthesis involves the reaction between hydrazines and $\beta$ difunctional compounds and it was applied to the preparation of 4-amino-1-phenyl- $1 H$-pyrazole3,5-dicarbonitrile 1 (Figure 1). ${ }^{[8]}$ This methodology was initially used by our research group to Address correspondence to M. S. T. Gonçalves, Chemistry Centre, University of Minho, Campus de Gualtar, 4710-057 Braga, Portugal. Tel: + 351253 604372. Fax: + 351253 604386. E-mail: msameiro@quimica.uminho.pt 
synthesise aminocyanopyrazoles containing a carboxylic ester group, such as compounds 2 (Figure 1). ${ }^{[9]}$ Following this successful work, similar heterocyclic compounds $\mathbf{4}$ containing a cyano group in the pyrazole ring replacing the ethyl ester were obtained by the same route. ${ }^{[10]}$ (Scheme 1) The synthesis started by diazotisation of $m$-aminobenzoic acids and further reaction of the resulting diazonium salts with malononitrile giving (dicyanomethylidene-hydrazino)benzoic acids $\mathbf{3}$, which cyclised by treatment with chloroacetonitrile in DMF, triethylamine being used as the base. ${ }^{[8]}$ When the results obtained by heating the reaction mixtures at reflux for short periods (5-15 minutes) were compared to those of heating at $80-90{ }^{\circ} \mathrm{C}$ for longer times (1-4 hours), it was found that in some cases, the last procedure led to lower yields and this was attributed to possible decomposition (TLC) and/or formation of by-products which was not investigated at that point.

\section{$<$ Figure 1>}

As part of our research interest in the synthesis and study of pyrazoles and their related

fused heterocycles, ${ }^{[9-14]}$ it was decided to reconsider the previously reported synthesis and use other bases, namely 1,8-diazabicyclo[5.4.0]undec-7-ene (DBU) and sodium hydride. The products were identified as the pyrazolo[4,3-d]pyrimidines 5, the para substituted cyanomethyl benzoates $\mathbf{6}$, and the expected pyrazoles $4^{[10]}$

\section{RESULTS AND DISCUSSION}

3-[2-(Dicyanomethylene)hydrazinyl]-(5-(un)substituted)-benzoic acids 3, obtained by diazotisation of the corresponding aminobenzoic acids followed by reaction with malononitrile, ${ }^{[10]}$ were reacted with chloroacetonitrile in DMF using a non-nucleophilic organic base or an inorganic base, namely DBU or sodium hydride, respectively (Scheme 1). After purification by column chromatography in silica gel, pyrazolo[4,3-d]pyrimidines 5, and para substituted cyanomethyl benzoates $\mathbf{6}$, were 
isolated simultaneously with the expected pyrazoles $\mathbf{4}$, in variable yields, as shown in Table 1 . The open chain ester, such as compound 7, was observed in all the experiments on TLC, but only 7a was quantitatively determined for the reaction from 3-[2-(dicyanomethylene)hydrazinyl]benzoic acid 3a.

\section{$<$ Scheme 1>}

Cyclisation of 3-[2-(dicyanomethylene)hydrazinyl]benzoic acid 3a using sodium hydride added stepwise gave the best yields for the pyrazoles $\mathbf{4 a}$, and pyrazolo[4,3-d]pyrimidine $\mathbf{5 a}$; and the cyanomethylester $\mathbf{7 a}$ was also isolated (Table 1, entry 1). Starting from precursor $\mathbf{3 b}$, and using the same base, pyrazolo[4,3-d]pyrimidine $\mathbf{5 b}$ was obtained in addition to the pyrazole $\mathbf{4 b}$ and the cyanomethyl ester $\mathbf{6 b}$ (Table 1, entry 3).

When these reactions were repeated under the same conditions they were found not reproducible. Thus, it was decided to use DBU as the base when the yields of pyrazoles $\mathbf{4 a}$ and $\mathbf{4 b}$ were 17 and $21 \%$, respectively (Table 1 , entries 2 and 4 ).

The cyclisation of $\mathbf{3 c}$ with DBU gave a low yield of the pyrazole $\mathbf{4 c}$ and this preparation was repeated for a shorter period with a minute improvement (Table 1, entries 5 and 6). Reaction under the same conditions with the methoxylated compound 3d gave the lowest yield and it was decided to repeat the reaction using a larger excess of base and no solvent which, however, gave a slight improvement only (Table 1, entries 7 and 8).

\section{<Table 1>}

Compounds $\mathbf{5}$ and $\mathbf{6}$ were fully characterised by high resolution mass spectrometry or elemental analysis, IR and NMR $\left({ }^{1} \mathrm{H}\right.$ and $\left.{ }^{13} \mathrm{C}\right)$ spectroscopy. Compounds $\mathbf{4}^{[10]}$ and $\mathbf{7 a}{ }^{[9]}$ were described before. 
The main feature on the ${ }^{1} \mathrm{H}$ NMR spectra for pyrazolo[4,3- $\left.d\right]$ pyrimidines $\mathbf{5 a - d}$ is the position of the $\mathrm{NH}_{2}$ that moves to $7.41-7.45$ (acetone- $\mathrm{d}_{6}$ ) or to $8.16-8.20$ (DMSO- $\mathrm{d}_{6}$ ) ppm, as compared with 6.50-6.68 $\left(\mathrm{DMSO}_{6} \mathrm{~d}_{6}\right.$ ) (for 4a-d), ${ }^{[10]}$ while the remaining signals do not change significantly. Their EI mass spectra showed always a molecular ion that was 52 units higher than that of the corresponding aminopyrazoles $4 \mathbf{a}-\mathbf{d} .{ }^{[10]}$ In their EI mass spectra losses due to the ester side chain were observed together with ions due to loss of $52\left(\mathrm{C}_{2} \mathrm{~N}_{2}\right)$ or $53\left(\mathrm{C}_{2} \mathrm{~N}_{2}+\mathrm{H}\right)$ that might result from cleavage on the pyrazole or pyrimidine moieties.

A detailed analysis of the ${ }^{13} \mathrm{C}$ NMR data showed a set of signals which was very similar in both the corresponding aminopyrazole $4 \mathbf{a}^{-\mathbf{d}^{[10]}}$ and the new compound 5a-d, and this was assigned to the benzene nucleus. Three signals for cyano groups could be observed for all the compounds, for example for compound $\mathbf{5 d}$ they appear at 116.2, 115.1 and 116.0.

The full assignment of ${ }^{13} \mathrm{C}$ signals for compound $\mathbf{5 d}$ was carried out by bidimensional heteronuclear HMBC and HMQC correlation techniques and this allowed us to conclude that they would fit the proposed structure.

The IR spectra of these fused heterocycles $\mathbf{5 a} \mathbf{a}-\mathbf{d}$, as in the case of pyrazoles $\mathbf{4 a - d},{ }^{[10]}$ showed the expected bands, due to stretching vibrations of the cyano groups $\left(2220-2250 \mathrm{~cm}^{-1}\right)$, the amine (3225-3500 $\left.\mathrm{cm}^{-1}\right)$ and ester functions $\left(1707-1735 \mathrm{~cm}^{-1}\right)$, as well as a strong band of the $\mathrm{C}=\mathrm{N}$ bond $\left(1588-1643 \mathrm{~cm}^{-1}\right)$ as result of the heterocyclic ring.

In most preparations a by-product identified as the para substituted cyanomethyl benzoate $\mathbf{6}$, was also isolated, and its ${ }^{1} \mathrm{H}$ NMR spectrum was conclusive showing signals due to an aromatic ring containing two substituents in para position and a methylenic signal at about $5 \mathrm{ppm}$. Although the cyano absorption band was not present in the IR spectrum it is known that the intensity of such band may be very low. ${ }^{[15]}$ Therefore, and since the amounts obtained were minute, it was decided to prepare the esters $\mathbf{6 c}$ and $\mathbf{6 d}$, by an independent method, from the corresponding benzoic acids and chloroacetonitrile. The ${ }^{1} \mathrm{H}$ NMR showed two doublets in the aromatic region and the methylenic group at $\delta 4.89(\mathbf{6 c})$ or $4.93(\mathbf{6 d}) \mathrm{ppm}$, but no cyano group was detected on their IR spectra. When 
EI mass spectra were obtained, however, they showed the expected $\mathrm{M}^{+}$ion, and also the base peak corresponding to loss of the fragment $\mathrm{OCH}_{2} \mathrm{CN}$. For both compounds, ${ }^{13} \mathrm{C}$ NMR spectra also showed a signal at $\delta 115.9(\mathbf{6 c})$ or $116.2(\mathbf{6 d}) \mathrm{ppm}$, that was attributed to the cyano carbon. It is thought that these compounds are very prone to hydrolysis and this might explain why, to the knowledge of the authors, they were not reported in the literature before.

In order to understand the pathway leading to compounds $\mathbf{4 , 5}$ and $\mathbf{6}$, an NMR study was carried out on the evolution of compound $\mathbf{3}$, in DMF and in the presence of DBU and chloroacetonitrile. The starting material 3 (15 mg) was dissolved in DMF-d $\mathrm{d}_{6}(0.5 \mathrm{~mL})$ in an NMR tube, 2 equivalents of both chloroacetonitrile and DBU were added and the NMR spectra were registered after 30, 60, 90 and 120 minutes. The signals at $\delta 8.0-8.20,7.53,6.97,6.70$ and $6.53 \mathrm{ppm}$ from compounds $\mathbf{6}, \mathbf{3}, \mathbf{5}$, hydrocyanic acid and $\mathbf{4}$, respectively, were followed to quantify the relative ratio of these materials in solution. The results obtained from this study are shown in Figure 2. They indicate that the disappearance of the starting material originated mainly compound $\mathbf{4}$ and that compounds 5 and $\mathbf{6}$ were always present in a 1:1 molar ratio. After 30 minutes at room temperature, $9.6 \%$ of $\mathbf{4}, 2.4 \%$ of hydrocyanic acid and $0.6 \%$ of both $\mathbf{5}$ and $\mathbf{6}$ were identified in solution. After a period of 2 hours the reaction mixture still contained approximately $50 \%$ of the starting material 3, together with $22 \%$ of $\mathbf{4}, 4.6 \%$ of hydrocyanic acid, $10 \%$ of $\mathbf{6}$ and $10 \%$ of $\mathbf{5}$. This suggests that the major pathway leads to the formation of compound $\mathbf{4}$ from the reaction of $\mathbf{3}$ with chloroacetonitrile. The formation of $\mathbf{5}$ possibly results from the reaction between two molecules of 4, eliminating hydrocyanic acid and the aromatic moiety $\mathbf{6}$. The compound mixture generated in the NMR study was separated by PLC, confirming the structure assignment to all the heterocyclic/aromatic products.

\section{$<$ Figure 2>}




\section{EXPERIMENTAL}

Melting points were measured on a Gallenkamp melting-point apparatus and are uncorrected. IR spectra were registered on a Perkin Elmer FTIR-1600. UV spectra were determined on a Hitachi U-2000. NMR spectra were obtained on a Varian Unity Plus Spectrometer at an operating frequency of $300 \mathrm{MHz}$ for ${ }^{1} \mathrm{H}$ NMR and $75.4 \mathrm{MHz}$ for ${ }^{13} \mathrm{C}$ NMR or a Bruker Avance III 400 at an operating frequency of $400 \mathrm{MHz}$ for ${ }^{1} \mathrm{H}$ NMR and $100.6 \mathrm{MHz}$ for ${ }^{13} \mathrm{C}$ NMR using the solvent peak as internal reference at $25^{\circ} \mathrm{C}$. All chemical shifts are given in ppm using $\delta_{\mathrm{H}} \mathrm{Me}_{4} \mathrm{Si}=0$ ppm as reference and $J$ values are given in Hz. Assignments were made by comparison of chemical shifts, peak multiplicities and $J$ values and were supported by spin decoupling-double resonance and bidimensional heteronuclear HMBC and HMQC correlation techniques.

Low resolution EI mass spectra were determined on a Unicam GC-MS 120. High resolution mass spectra were obtained on a VG Ultima or AutoSpec E spectrometers. Elemental analyses were obtained on a Leco CHNS-932. TLC (Thin Layer Chromatography) and PLC (Preparative Layer Chromatography) were carried out on plates coated with silica gel $60 \mathrm{~F}_{254}$. Column chromatography was performed on silica gel $(<230$ mesh) with mixtures of light petroleum and diethyl ether of increasing polarity, unless other conditions are described. Light petroleum refers to the fraction boiling in the range $40-60{ }^{\circ} \mathrm{C}$.

\section{General Procedures for the Cyclisation of Compounds 3a-d}

\section{Method 1}

To a solution of the intermediate $(3,1$ mequiv.) in dry DMF $(1.6 \mathrm{~mL}), \mathrm{DBU}$ (x mequiv.), and chloroacetonitrile (2.2 mequiv.) were added and the mixture was kept stirring at the temperature and time indicated in Table 1. After cooling the solvent was removed under reduced pressure and the dark oily mixture obtained was purified by column chromatography or PLC. 


\section{Method 2}

$\mathrm{NaH}$ (2.2 or 4.2 mequiv.) was suspended in DMF (2 mL) and a solution of the intermediate (1 mequiv.) in DMF (3 mL) was added slowly, with stirring. Chloroacetonitrile (2.2 mequiv.) was added and the mixture heated at the temperature and for the time mentioned in Table 1.

After cooling, water was added, and then $6 \mathrm{~N} \mathrm{HCl}$ until a dark solid precipitated. This was filtered, dried in the oven $\left(45^{\circ} \mathrm{C}\right)$ and purified by chromatography. In some of the attempts only water was added and a brown oil separated which was extracted with acetone. The solvent was removed and the resulting oil was purified by column chromatography or PLC.

\section{Cyanomethyl 3-(7-amino-3,5-dicyano-1H-pyrazolo[4,3- $d]$ pyrimidin-1-yl)benzoate 5a}

After column chromatography, the pyrazolopyrimidine 5a was obtained as a yellow solid (21\%), mp 225.9-228.6 ${ }^{\circ} \mathrm{C}, \mathrm{IR}\left(\mathrm{KBr}, \mathrm{cm}^{-1}\right): 3500,3317,3225,2960,2920,2232,2220,1732,1633$, 1571; UV (EtOH): $230 \mathrm{~nm}\left(\log \varepsilon\right.$ 4.48), $260 \mathrm{~nm}\left(\log \varepsilon\right.$ 4.27), $375 \mathrm{~nm}(\log \varepsilon 3.91) ;{ }^{1} \mathrm{H}$ NMR (300 MHz, DMSO-d 6$): 5.29\left(2 \mathrm{H}, \mathrm{s}, \mathrm{CH}_{2}\right), 7.84(1 \mathrm{H}, \mathrm{t} J 8.0 \mathrm{~Hz}, 5-\mathrm{H}), 8.08(1 \mathrm{H}, \mathrm{dt} J 8.0$ and $1.0 \mathrm{~Hz}, 4-\mathrm{H})$, $8.25\left(2 \mathrm{H}\right.$, br s, $\left.\mathrm{NH}_{2}\right), 8.42-8.48(1 \mathrm{H}, \mathrm{m}, 6-\mathrm{H}), 8.61(1 \mathrm{H}, \mathrm{t} J 1.0 \mathrm{~Hz}, 2-\mathrm{H}) ;{ }^{13} \mathrm{C}$ NMR $(75.4 \mathrm{MHz}$, DMSO-d $\left.{ }_{6}\right): 50.12\left(\mathrm{CH}_{2}\right), 111.5,115.0(\mathrm{CN}), 115.8(\mathrm{CN}), 116.3\left(\mathrm{CH}_{2} \mathrm{CN}\right), 119.9,122.2,126.8$, 128.9, 129.3, 130.4, 130.6, 137.7, 143.8, 155.6 (C-7'), 163.9 (CO); m/z (\%) (EI) $345\left(\mathrm{M}^{+}+1,24\right)$, $344\left(\mathrm{M}^{+}, 100\right), 292\left(\mathrm{M}^{+}-\mathrm{C}_{2} \mathrm{~N}_{2}, 12\right), 288\left(\mathrm{M}^{+}-\mathrm{OCH}_{2} \mathrm{CN}, 87\right), 287$ (21), 261 (11), $260\left(\mathrm{M}^{+}-\right.$ $\left.\mathrm{CO}_{2} \mathrm{CH}_{2} \mathrm{CN}, 27\right), 208$ (41), 207 (21), 206 (32), 181 (34), 144 (54), 129 (23), 119 (18), 116 (21), 103 (23), 102 (52), 92 (30), 90 (22), 83 (16), 77 (22), 76 (31), 66 (24), 65 (33), 64 (99), 63 (49), 61 (52). Anal. calcd. for $\mathrm{C}_{16} \mathrm{H}_{8} \mathrm{~N}_{8} \mathrm{O}_{2}:$ C, 55.82; H, 2.33; N, $32.56 \%$. Found: $\mathrm{C}, 55.62 ; \mathrm{H}, 2.5 ; \mathrm{N}, 32.30 \%$. 


\section{Cyanomethyl 3-(7-amino-3,5-dicyano-1H-pyrazolo[4,3- $d$ ]pyrimidin-1-yl)-4-methylben-}

zoate 5b

After column chromatography followed by washing with diethyl ether the pyrazolopyrimidine $\mathbf{5 b}$ was obtained as a yellow solid $(32 \%), \mathrm{mp} 253.8-255.2{ }^{\circ} \mathrm{C}, \mathrm{IR}\left(\mathrm{KBr}, \mathrm{cm}^{-1}\right)$ : 3340, 3332, 3236, 2250, 2240, 1735, 1645, 1630, 1571; UV (EtOH): $230 \mathrm{~nm}(\log \varepsilon 4.32), 315 \mathrm{~nm}$ ( $\log \varepsilon$ 3.70), $375 \mathrm{~nm}\left(\log \varepsilon\right.$ 4.04); ${ }^{1} \mathrm{H}$ RMN (300 MHz, acetone-d $\left.\mathrm{d}_{6}\right): 2.34(3 \mathrm{H}, \mathrm{s}, \mathrm{Me}), 5.26(2 \mathrm{H}, \mathrm{s}$, $\left.\mathrm{CH}_{2}\right), 7.45\left(2 \mathrm{H}\right.$, br s, $\left.\mathrm{NH}_{2}\right), 7.76(1 \mathrm{H}, \mathrm{d} J 7.6 \mathrm{~Hz}, 5-\mathrm{H}), 8.18-8.20(1 \mathrm{H}$, br s, $2-\mathrm{H}), 8.22(1 \mathrm{H}, \mathrm{dd} J 7.6$ and $1.9 \mathrm{~Hz}, 6-\mathrm{H}) ;{ }^{13} \mathrm{C}$ NMR (75.4 MHz, DMSO-d 6$): 17.7\left(\mathrm{CH}_{3}\right), 49.9\left(\mathrm{CH}_{2}\right), 115.0(\mathrm{CN}), 115.8$ $(\mathrm{CN}), 115.9\left(\mathrm{CH}_{2} \underline{\mathrm{CN}}\right), 116.6,119.6,125.8,126.7,128.9,130.9,132.1,142.2,144.4,155.8$ (C-7'), $163.5(\mathrm{CO}) ; \mathrm{m} / \mathrm{z}(\mathrm{EI})(\%) 359\left(\mathrm{M}^{+}+1,22\right), 358\left(\mathrm{M}^{+}, 91\right), 357(24), 318\left(\mathrm{M}^{+}-\mathrm{CH}_{2} \mathrm{CN}, 47\right), 306\left(\mathrm{M}^{+}\right.$ - $\left.\mathrm{C}_{2} \mathrm{~N}_{2}, 48\right), 305$ (79), $302\left(\mathrm{M}^{+}-\mathrm{OCH}_{2} \mathrm{CN}, 17\right), 274\left(\mathrm{M}^{+}-\mathrm{CO}_{2} \mathrm{CH}_{2} \mathrm{CN}, 16\right), 273$ (14), 239 (18), 222 (40), 221 (19), 214 (38), 104 (21), 103 (53), 102 (24), 92 (35), 91 (33), 90 (45), 89 (100), 78 (45), 77 (78), 76 (46). HRMS (EI): calcd for $\mathrm{C}_{17} \mathrm{H}_{10} \mathrm{~N}_{8} \mathrm{O}_{2}\left[\mathrm{M}^{+}\right]$: 358.0929; found: 358.0916 .

\section{Cyanomethyl 3-(7-amino-3,5-dicyano-1H-pyrazolo[4,3-d]pyrimidin-1-yl)-4-chloroben-} zoate 5c

After colunm chromatography followed by PLC, the pyrazolopyrimidine $\mathbf{5 c}$ was obtained as a yellow solid (4 or $10 \%)$, mp 233.7-235.7 ${ }^{\circ} \mathrm{C}$; IR $\left(\mathrm{KBr}, \mathrm{cm}^{-1}\right): 3454,3343,3250,2241,1733$, 1622, 1585, 1571, 1541; UV (EtOH): $230 \mathrm{~nm}(\log \varepsilon$ 3.48), $300 \mathrm{~nm}(\log \varepsilon 3.45) \mathrm{nm}, 375(\log \varepsilon$ 3.78); ${ }^{1} \mathrm{H}$ NMR (300 MHz, DMSO-d 6 ): $5.22\left(2 \mathrm{H}, \mathrm{s}, \mathrm{CH}_{2}\right), 7.98(1 \mathrm{H}, \mathrm{d} J 8 \mathrm{~Hz}, 5-\mathrm{H}), 8.16$ (2H, br s, $\left.\mathrm{NH}_{2}\right), 8.20(1 \mathrm{H}$, dd $J 8$ and $2 \mathrm{~Hz}, 6-\mathrm{H}), 8.31(1 \mathrm{H}, \mathrm{d} J 2 \mathrm{~Hz}, 2-\mathrm{H}) ;{ }^{13} \mathrm{C}$ NMR $\left(75.4 \mathrm{MHz}, \mathrm{DMSO}-\mathrm{d}_{6}\right)$ : $49.9\left(\mathrm{CH}_{2}\right), 115.0(\mathrm{CN}), 115.5,115.8(\mathrm{CN}), 116.5\left(\mathrm{CH}_{2} \underline{\mathrm{CN}}\right), 120.3,125.5,131.3,131.6,133.0$, 134.0, 128.3, 137.1, 144.9, 156.0 (C-7'), 163.0 (CO); HRMS (EI): calcd for $\left.\mathrm{C}_{16} \mathrm{H}_{7} \mathrm{~N}_{8} \mathrm{O}_{2}{ }^{35} \mathrm{Cl}^{2} \mathrm{M}^{+}\right]$: 378.0383; found: 378.0366 . 


\section{Cyanomethyl 3-(7-amino-3,5-dicyano-1H-pyrazolo[4,3- $d]$ pyrimidin-1-yl)-4-methoxy-}

\section{benzoate $5 d$}

After column chromatography followed by PLC, the pyrazolopyrimidine $\mathbf{5 d}$ was obtained as a yellow solid $(2$ or $10 \%)$, that decomposes at $200{ }^{\circ} \mathrm{C}$ without melting; IR ( $\left.\mathrm{KBr}, \mathrm{cm}^{-1}\right): 3473$, 3366, 2242, 2228, 1707; UV (EtOH): $234 \mathrm{~nm}(\log \varepsilon$ 4.41), $308 \mathrm{~nm}(\log \varepsilon 3.70) \mathrm{nm}, 374 \mathrm{~nm}(\log \varepsilon$

3.98); ${ }^{1} \mathrm{H}$ NMR (400 MHz, DMSO-d 6 ): $3.87\left(3 \mathrm{H}, \mathrm{s}, \mathrm{OCH}_{3}\right), 5.21\left(2 \mathrm{H}, \mathrm{s}, \mathrm{CH}_{2}\right), 7.49(1 \mathrm{H}, \mathrm{d} J 8.8$ $\mathrm{Hz}, 5-\mathrm{H}), 8.06\left(2 \mathrm{H}\right.$, br s, $\left.\mathrm{NH}_{2}\right), 8.13(1 \mathrm{H}, \mathrm{d} J 2 \mathrm{~Hz}, 2-\mathrm{H}), 8.23(1 \mathrm{H}$, dd $J 8.8$ and $2.4 \mathrm{~Hz}, 6-\mathrm{H})$; ${ }^{13} \mathrm{C}$ NMR (100.6 MHz, DMSO-d 6$): 49.9\left(\mathrm{CH}_{2}\right), 56.8\left(\mathrm{OCH}_{3}\right), 113.5(\mathrm{C}-5), 115.1(\mathrm{CN}), 116.0(\mathrm{CN})$, $116.2\left(\mathrm{CH}_{2} \underline{\mathrm{CN}}\right), 119.6$ (C-3' or C-7’a), 120.3 (C-1), 124.7 (C-3), 125.5 (C-3' or C-7'a), 130.8 (C2), 133.9 (C-6), 144.8 (C-5'), 155.9 (C-7’), 159.3 (C-4), 163.4 (CO); HRMS (EI): calcd for $\mathrm{C}_{17} \mathrm{H}_{10} \mathrm{~N}_{8} \mathrm{O}_{3}\left[\mathrm{M}^{+}\right]$: 374.087586; found: 374.086754 .

\section{Esters 6 as obtained during the preparation of pyrazoles 4.}

\section{Cyanomethyl 4-methylbenzoate 6b}

After PLC the ester $6 \mathbf{b}$ was obtained as an oil (6\%); IR (neat) $\left(\mathrm{cm}^{-1}\right): 2921,2838,1729$, 1612; ${ }^{1} \mathrm{H}$ NMR (300 MHz, $\left.\mathrm{CDCl}_{3}\right): 2.45\left(3 \mathrm{H}, \mathrm{s}, \mathrm{CH}_{3}\right), 4.97\left(2 \mathrm{H}, \mathrm{s}, \mathrm{CH}_{2}\right), 7.30(2 \mathrm{H}, \mathrm{d} J 8.2 \mathrm{~Hz}, 3-\mathrm{H}$ and 5-H), $7.96\left(2 \mathrm{H}, \mathrm{d} J 8.2 \mathrm{~Hz}, 2-\mathrm{H}\right.$ and 6-H); m/z (\%) (EI) $175\left(\mathrm{M}^{+}, 14\right), 120(9), 119\left(\mathrm{M}^{+}\right.$$\left.\mathrm{OCH}_{2} \mathrm{CN}, 100\right), 91$ (39), 89 (10), 65 (4).

\section{Cyanomethyl 4-chlorobenzoate 6c}

After column chromatography followed by PLC, ester $\mathbf{6 c}$ was obtained as a white oil that later solidified (18\%); the experimental data confirmed its structure and were in accordance with those described below obtained in an independent synthesis. 


\section{Cyanomethyl 4-methoxybenzoate 6d}

After column chromatography and PLC, the ester 6d was obtained as a colourless oil that later solidified $(3 \%), \mathrm{mp} 58.9-59.7{ }^{\circ} \mathrm{C}$; the experimental data confirmed its structure and were in accordance with those described below obtained in an independent synthesis.

\section{Synthesis of the esters $6 c$ and $6 d$.}

\section{Cyanomethyl 4-chlorobenzoate 6c}

To a solution of $p$-chlorobenzoic acid (0.5 g, 3.2 mequiv.) in dry DMF (3 mL), potassium carbonate (0.44 g, 3.2 mequiv.) and chloroacetonitrile $(0.2 \mathrm{~mL}, 3.2$ mequiv.) were added and the mixture was kept stirring overnight. Water was added and the mixture was extracted with ether. The organic extracts were dried $\left(\mathrm{MgSO}_{4}\right)$ and the solvent removed to give ester $\mathbf{6 c}$ as an oil which later solidified (0.41 g, $65 \%), \mathrm{mp} 48.5-50.3{ }^{\circ} \mathrm{C}$; IR (neat, $\mathrm{cm}^{-1}$ ): 3455, 2943, 1736, 1670, 1589; ${ }^{1} \mathrm{H}$ NMR (300 MHz, $\left.\mathrm{CDCl}_{3}\right): 4.89\left(2 \mathrm{H}, \mathrm{s}, \mathrm{CH}_{2}\right), 7.27(2 \mathrm{H}, \mathrm{d} J 9 \mathrm{~Hz}, 3$ and 5-H) $7.80(2 \mathrm{H}, \mathrm{d} J$ 9Hz, 2 and 6H). ${ }^{13} \mathrm{C}$ NMR (75.4 MHz, DMSO-d 6 ): $50.0\left(\mathrm{CH}_{2}\right), 115.9(\mathrm{CN}), 126.8(\mathrm{C}-1), 129.2(\mathrm{C}-3$ and C-5), $131.3\left(\mathrm{C}-2\right.$ and C-6), $139.2(\mathrm{C}-4), 163.9(\mathrm{C}=\mathrm{O}) ; \mathrm{m} / \mathrm{z}(\%)(\mathrm{EI}) 197\left(\mathrm{M}^{+},{ }^{37} \mathrm{Cl}, 30\right), 195\left(\mathrm{M}^{+},{ }^{35} \mathrm{Cl}, 84\right)$, 141 (34), 139 (100), 113 (24), 111 (72), 76 (19), 75 (57), 74 (26). Anal. calcd. for $\mathrm{C}_{9} \mathrm{H}_{6} \mathrm{NO}_{2} \mathrm{Cl}$ : C, 55.26; H, 3.09; N, 7.16\%. Found: C, 55.50; H, 3.05; N, 7.15.

\section{Cyanomethyl 4-methoxybenzoate 6d}

Following the method just described for $\mathbf{6 c}$ and using $p$-methoxybenzoic acid, the ester $\mathbf{6 d}$ was obtained as a reddish brown solid $(79 \%), \mathrm{mp} 60.2-62.0{ }^{\circ} \mathrm{C}$; IR $\left(\mathrm{KBr}, \mathrm{cm}^{-1}\right): 3426,3014,2972$, 2939, 2844, 1916, 1724, 1608, 1580, 1513; ${ }^{1} \mathrm{H}$ NMR (300 MHz, DMSO-d 6 ): $3.84\left(3 \mathrm{H}, \mathrm{s}, \mathrm{OCH}_{3}\right)$, $5.17\left(2 \mathrm{H}, \mathrm{s}, \mathrm{CH}_{2}\right), 7.09(2 \mathrm{H}$, dd $J 6.1$ and $2.1 \mathrm{~Hz}, 3-\mathrm{H}$ and 5-H), $7.95(2 \mathrm{H}$, dd $J 6.9$ and 2.1 Hz, 2-H and 6-H); ${ }^{13} \mathrm{C}$ NMR (75.4 MHz, DMSO-d 6$): 49.5\left(\mathrm{CH}_{2}\right), 55.7\left(\mathrm{OCH}_{3}\right), 114.4(\mathrm{C}-3$ and $\mathrm{C}-5), 116.2$ (CN), 120.0 (C-1), 131.8 (C-2 and C-6), 163.9 (C-4), 164.3 (CO); m/z (EI) (\%) $192\left(\mathrm{M}^{+}+1,8\right), 191$ 
$\left(\mathrm{M}^{+}, 57\right), 136$ (10), $135\left(\mathrm{M}^{+}-\mathrm{OCH}_{2} \mathrm{CN}, 100\right), 107$ (14), 92 (29), 77 (13), 64 (6). HRMS (EI): calcd for $\mathrm{C}_{10} \mathrm{H}_{19} \mathrm{NO}_{3}\left[\mathrm{M}^{+}\right]:$191.058243; found: 191.058294 .

\section{ACKNOWLEDGEMENTS}

We thank Junta Nacional de Investigação Científica e Tecnológica (Portugal) for financial support through (IBQF-UM) and PRAXIS XXI for support under project PRAXIS/ 2/ 2.1/ QUI/ 44/ 94 and for a scholarship to M.S.T. Gonçalves (BD-2566-93-RM). The NMR spectrometer Bruker Avance III 400 is part of the National NMR Network and was purchased in the framework of the National Program for Scientific Re-equipment, contract REDE/1517/RMN/2005 with funds from POCI 2010 (FEDER) and FCT. To Miss Elisa Pinto for obtaining the NMR, low resolution mass and elemental analyses data.

\section{REFERENCES}

[1] Larsen, J. S.; Zahran, M. A.; Pedersen, E. B.; Nielsen, C. Synthesis of triazenopyrazole derivatives as potential inhibitors of HIV-1. Monatsh. Chem. 1999, 130, 1167-1173.

[2] Dai, H.; Li, Y. Q.; Du, D.; Qin, X.; Zhang, X.; Yu, H. B.; Fang J. X. Synthesis and biological activities of novel pyrazole oxime derivatives containing a 2-chloro-5-thiazolyl moiety. J. Agric. Food Chem. 2008, 56, 10805-10810.

[3] Rashad, A. E.; Hegab, M. I.; Abdel-Megeid, R. E.; Micky, J. A.; Abdel-Megeid, F. M. E. Synthesis and antiviral evaluation of some new pyrazole and fused pyrazolopyrimidine derivatives. Bioorg. Med. Chem. 2008, 16, 7102-7106.

[4] Bouabdallah, I.; M'barek, L. A.; Zyad, A.; Ramadan, A.; Zidane, I.; Melhaoui, A. Anticancer effect of three pyrazole derivatives. Nat. Prod. Res. 2006, 20, 1024-1030.

[5] Pinto, D. J. P.; Quan, M. L.; Woerner, F. J.; Li, R., Int. Patent WO 02000655 A1, 2002. 
[6] Brady, T.; Vu, K.; Barber, J. R.; Ng, S. C.; Zhou, Y. Synthesis of novel 2,3-substituted-2,4dihydro-pyrazolo[4,3-d]pyrimidine-5,7-diones. Tetrahedron Lett. 2009, 50, 6223-6227.

[7] Semeraro, T.; Mugnaini, C.; Manetti, F.; Pasquini, S.; Corelli, F. Practical synthesis of novel purine analogues as Hsp90 inhibitors. Tetrahedron 2008, 64, 11249-11255.

[8] Gewald, K.; Jaensch H. J.; Calderon, O., E. Ger. Patent 113 359, 1975.

[9] Moura, J. C. V. P.; Oliveira-Campos, A. M. F.; Griffiths, J.; Maia, H. L. S.; Gomes, J. I. N. R. Synthesis of carboxylic acid derivatives of aminocyanopyrazoles: useful precursors for a new class of fiber-reactive azo dyes. J. Chem. Res. 1995, (S), 128-129; (M), 924-937 (Part I).

[10] Gonçalves, M. S. T.; Oliveira-Campos, A. M. F.; Rodrigues, L. M.; Proença, M. F. R. P. Griffiths, J.; Maia, H. L. S.; Kaja, M.; Hrdina, R. Synthesis of novel derivatives of 4-amino-3,5dicyanopyrazole. J. Chem. Res. 2004, 115-117.

[11] Oliveira-Campos, A. M. F.; Salaheldin, A. M.; Rodrigues, L. M. Synthesis of some novel pyrazolo[3,4-d]pyrimidine derivatives. ARKIVOC 2007, 16, 92-100.

[12] Gupta, S.; Rodrigues, L. M.; Esteves, A. P.; Oliveira-Campos, A. M. F.; Nascimento, M. S. J.; Nazareth, N.; Cidade, H.; Neves, M. P.; Fernandes, E.; Pinto, M.; Cerqueira, N. M. F. S. A.; Brás, $\mathrm{N}$. Synthesis of $\mathrm{N}$-aryl-5-amino-4-cyanopyrazole derivatives as potent xanthine oxidase inhibitors. Eur. J. Med. Chem. 2008, 43, 771-780.

[13] Salaheldin, A. M.; Oliveira-Campos, A. M. F.; Rodrigues, L. M. Heterocyclic synthesis with nitriles: synthesis of pyrazolopyrimidine and pyrazolopyridine derivatives. Synth. Commun. 12009 , 39, 1186-1195.

[14] Salaheldin, A. M.; Oliveira-Campos, A. M. F.; Rodrigues, L. M. 3-Aminopyrroles and their application in the synthesis of pyrrolo[3,2-d]pyrimidine (9-deazapurine) derivatives. ARKIVOC 2008, $14,180-190$. 
[15] Hosni, H. M.; Basyouni, W. M.; El-Nahas, H. A. Thienopyrimidines. Part III. Synthesis of novel substituted thieno[2,3-d]pyrimidinone derivatives and their condensed products with molluscicidal and larvicidal activities. J. Chem. Res. 1999, (S), 646-647; (M), 2775-2794. 


\section{TABLES}

\section{Table 1.}

\begin{tabular}{|c|c|c|c|c|c|c|c|}
\hline \multirow[b]{2}{*}{ Entry } & \multirow{2}{*}{$\begin{array}{l}\text { Starting } \\
\text { material }\end{array}$} & \multirow{2}{*}{$\begin{array}{c}\text { Time }(\mathrm{h}) / \\
\text { Temp. }\left({ }^{\circ} \mathrm{C}\right)^{\mathrm{a}}\end{array}$} & \multirow{2}{*}{$\begin{array}{c}\text { Base } \\
\text { (mequiv.) }\end{array}$} & \multicolumn{4}{|c|}{ Product yield (\%) } \\
\hline & & & & 4 & 5 & 6 & 7 \\
\hline 1 & $\mathbf{3 a}$ & $5 / 80+10 / 100$ & $\mathrm{NaH}(4.2)^{\mathrm{c}}$ & 54 & 21 & --- & 3 \\
\hline 2 & $3 \mathbf{a}^{\mathrm{b}}$ & 10 & DBU (2.2) & 17 & -- & -- & 3 \\
\hline 3 & $\mathbf{3 b}$ & $5 / 80+10 / 100$ & $\mathrm{NaH}(4.2)^{\mathrm{c}}$ & 16 & 32 & 6 & --- \\
\hline 4 & $3 \mathbf{b}$ & 10 & DBU (2.2) & 21 & --- & --- & --- \\
\hline 5 & $3 c$ & 10 & DBU (2.2) & 6 & 10 & 18 & --- \\
\hline 6 & $3 c$ & 2 & DBU (2.2) & 11 & 4 & --- & --- \\
\hline 7 & 3d & 2 & DBU (2.2) & 2 & 10 & --- & --- \\
\hline 8 & $3 d^{d}$ & 5 & DBU (6.0) & 14 & 2 & 3 & --- \\
\hline
\end{tabular}

${ }^{a}$ The reaction temperature was $100-120^{\circ} \mathrm{C}$ except when otherwise stated

${ }^{\mathrm{b}}$ Similar result was obtained when the reaction was carried out under $\mathrm{N}_{2}$

${ }^{\mathrm{c}}$ Stepwise addition of base

${ }^{\mathrm{d}}$ Reaction carried out without solvent 


\section{FIGURES}

Figure 1.

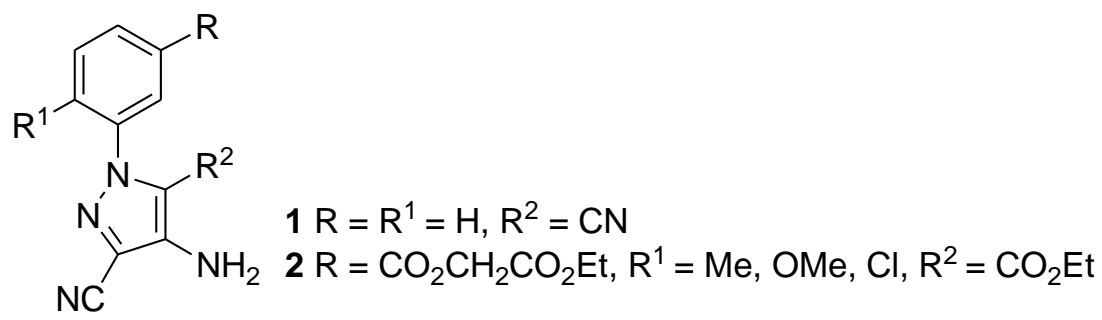


Figure 2.

\begin{tabular}{rrrrrr}
\hline \multicolumn{6}{c}{ Concentration (\%) of compounds } \\
\hline $\mathbf{t}$ (min) & \multicolumn{1}{c}{ 3d } & HCN & 6d & 5d & \multicolumn{1}{c}{ 4d } \\
\hline 0 & 100 & 0 & 0 & 0 & 0 \\
30 & 87 & 2.4 & 0.6 & 0.6 & 9.6 \\
60 & 72 & 4.3 & 5.6 & 5.6 & 12.5 \\
90 & 63 & 4.1 & 8.2 & 8.2 & 18.5 \\
120 & 53 & 4.6 & 10 & 10 & 22 \\
\hline
\end{tabular}

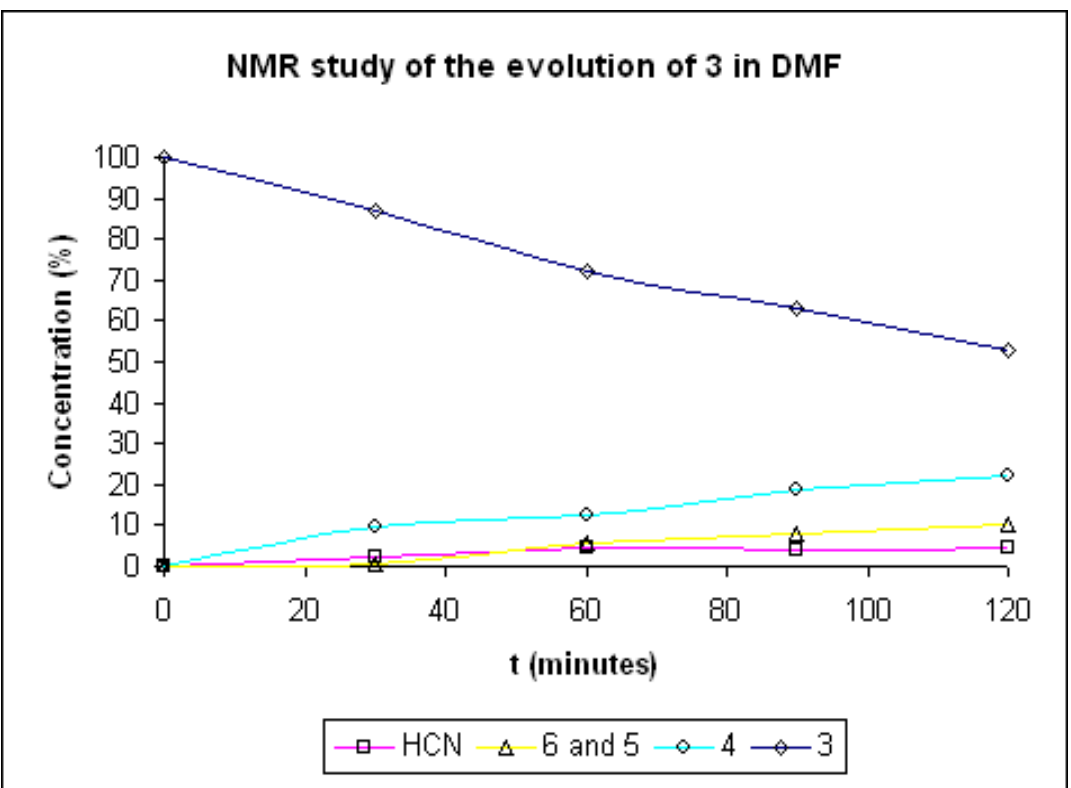




\section{SCHEMES}

Scheme 1.
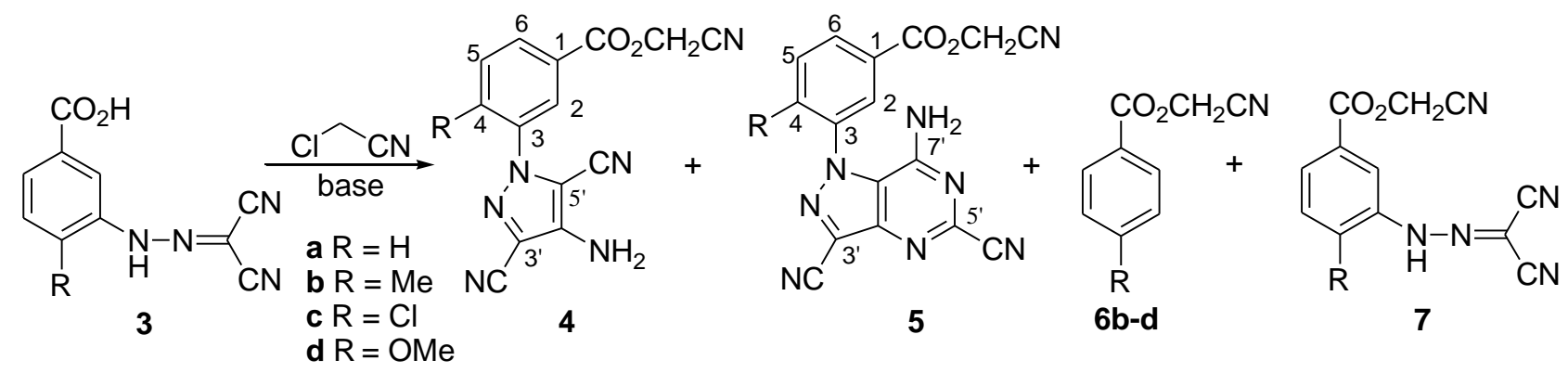


\section{LEGENDS}

Table 1. Experimental conditions, and yields for the synthesis of pyrazoles 4 (chloroacetonitrile, 2.2 mequiv., was used in all reactions).

Figure 1. Structure of pyrazoles 1 and 2.

Figure 2. NMR study of the evolution of $\mathbf{3 d}$ in DMF with DBU and chloroacetonitrile

Scheme 1. Synthesis of pyrazoles $\mathbf{4}$ and their secondary products. 